\title{
SCREENING FOR THE POTENTIAL BIOACTIVITIES OF JATROPHA CURCAS
}

\author{
S.Nagaswathi \\ Department of Microbiology \\ Sri Durga Malleswara Siddhartha Mahila Kalasala, \\ Vijayawada, Andhrapradesh, India
}

\author{
V.Jayalakshmi \\ Department of Microbiology \\ Sri Durga Malleswara Siddhartha Mahila Kalasala, \\ Vijayawada ,Andhrapradesh, India
}

\begin{abstract}
The potential use of Jatropha curcas $L$ was investigated by taking dried seeds. Seeds were then crushed, and oil was extracted using Rota evaporator apparatus from kernel seeds. The phytochemical screening of the oil shows the presence of some bioactive compounds like Antioxidants, Flavanoids, tannins etc. By Tran's esterification methods, we observe good amount of biodiesel by using methanol, $\mathrm{KOH}$ and ultra-sonication at lesser reaction time. In addition to these, In the present study the seedcake were obtained after extraction and it was analyzed to know its coagulation properties.
\end{abstract}

Keywords - Alkaloids, Jatropha curcas, Rota Evaporator, Transesterification.

\section{INTRODUCTION}

The fuels used in the industry and petroleum products produces high amounts of harmful gases like carbonmonooxide, nitrogen dioxide, chlorine etc that which causes air pollution and it also causes severe illness to living organisms. Several fuels are used in day to day activities i.e.; in shipping purposes etc. The presences of carbon and Hydrogen in fuel amalgamate with air where combustion takes place and liberates heat. From last 50 years there is a rapid increase in the release of toxic substances released into the environment by burning Fossil fuels produces high amount of oxides like sulphur and nitrogen.

\author{
N.Saritha \\ Department of Microbiology \\ Sri Durga Malleswara Siddhartha Mahila Kalasala, \\ Vijayawada, Andhra Pradesh, India \\ M.B.Sridevi \\ Department of Microbiology \\ Sri Durga Malleswara Siddhartha Mahila Kalasala, \\ Vijayawada, Andhra Pradesh ,India
}

At present there is an urgent need of replacing these harmful fuels with Biofuels to reduce the environmental pollution. Therefore in these current study showed that Jatropha curcas $L$ plays vital role in producing Biodiesel which has many advantages like ecofriendly, easily available and sustainable. The vegetable oils which extracted from Jatropha curcas $L$ used as a fuels in engines which is high in viscosity acts as a alternative Biofuel. The extraction and manufacturing of Biodiesel from Jatropha curcas $L$ is inexpensive, and nonedible and belongs to the family Euphorbiaceae.B100 is a pure Biodiesel used in any kind of petroleum engines for transportation Being a viable source, it is gaining attention all over the world today. Biodiesel was registered with U.S. Environmental protection Agency as a fuel under section 211(b) of clean Air Act, with the help of American Society of Testing And Materials (ASTM).(Nazar J., Ramesh A. and Nagalingam B.(2009) done Experimental Investigation on the Use of Vegetable Oil extracted from Jatropha curcas L in a performance Diesel Engine when used as a primary fuel in a ignition engine.

\section{Benefits of biodiesel}

The main benefit of Biodiesel extracted from Jatropha curcas $L$ is carbon neutral Biodiesel is rapidly biodegradable and completely non-toxic, meaning spillages represent far less of a risk than fossil diesel spillages. Biodiesel has a higher flash point than fossil diesel and so is safer in the event of a crash. 
Seeds: Seeds are mature when capsule changes from green to Yellow. They yield 25\% to $40 \%$ oil by weight and it also contain curcasin, Palmitic acids etc.

\begin{tabular}{|l|l|l|l|l|}
\hline Crop & $\begin{array}{l}\text { Kg } \\
\text { oil/ha }\end{array}$ & $\begin{array}{l}\text { Liters } \\
\text { oil/ha }\end{array}$ & $\begin{array}{l}\text { US } \\
\text { gal/acre }\end{array}$ & $\begin{array}{l}\text { Oil } \\
\text { Content }\end{array}$ \\
\hline $\begin{array}{l}\text { Castor } \\
\text { beans }\end{array}$ & 1188 & 1413 & 151 & $\begin{array}{l}50 \% \quad \\
55 \%\end{array}$ \\
\hline Coconut & 2260 & 2689 & 287 & $70 \%$ \\
\hline $\begin{array}{l}\text { Corn } \\
\text { (maize) }\end{array}$ & 145 & 172 & 18 & $12 \%$ \\
\hline Cotton & 273 & 325 & 35 & $\begin{array}{l}13 \% \\
15 \%\end{array}$ \\
\hline Jatropha & 1590 & 1892 & 202 & $\begin{array}{l}30 \% \\
35 \%\end{array}$ \\
\hline Palm oil & 5000 & 5950 & 635 & $35 \%$ \\
\hline Peanuts & 890 & 1059 & 113 & $36 \%$ \\
\hline Rapeseed & 1000 & 1190 & 127 & $37 \%$ \\
\hline Soybean & 375 & 446 & 48 & $15 \%$ \\
\hline
\end{tabular}

Genome: The whole genome was sequenced by Kazusa DNA Research Institute, Chiba Japan in October 2010.

Jatropha Curcas plants have the following unique qualitiesApproximately 33\% of oil yield Fast Growth and Low

Maintenance It has great Durability which is more than 45 yearsPer acre yield of 3.6 metric tons of fruits in the first three years and multiply after the third year. Transesterification process takes place in order to produce high quality of Biodiesel .In pilot Biodiesel Jatropha oil is blended with alcohol for transesterification reaction, the process is done under specific duration with reaction temperature and with vigorous agitation. After the reaction taken place the glycerol is mixed with the fuel in settling tank. The fuel is collected and washed to get pure Biodiesel. The fuel properties of jatropha biodiesel produced in the pilot plant are given in the shows the feedstock for biodiesel production and their physicochemical properties. "Gubitz et al. (2016)

\section{ADVANTAGES OF BIODIESEL:}

1. Produced from sustainable / renewable biological sources.

2. Eco-friendly and oxygenated fuel.

3. Sulphur free, less Carbon (CO) and HC, particulate matter and aromatic compound emissions. "Dennis et al. (2016)

4. Income to rural community.

5. Biodiesel provides better engine lubrication than Low Sulphur Petro diesel.

The process of Extracting oils from jatropha is as

Cultivation of Jatropha Curcuas L plants

Isolation of oils from seeds,

Refining

Transesterification

\section{BOTANICAL FEATURES}

Leaves: Five lobed with spiral Phyllotaxis

Flowers: Male and female flowers are produced, Petiole length ranges from 6.1 to $23.1 \mathrm{~nm}$.plant is monoecious and occasionally these are hermaphroditic.

Fruits: Fruits are produced during winter seasons some plants produced fruits throughout the season and some produces 2 to 3 times in a year

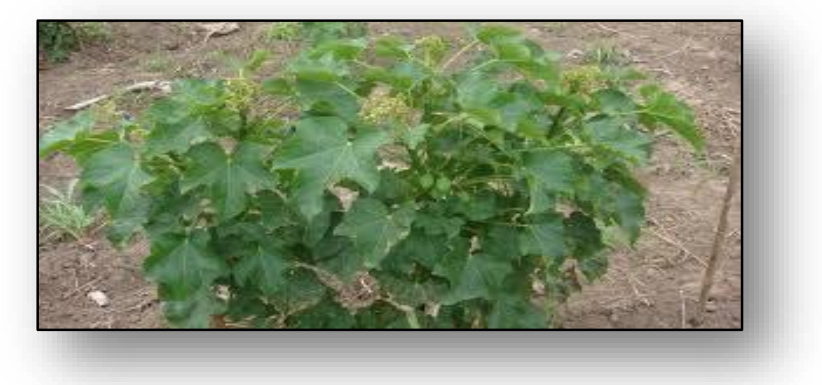

\section{MEDICINAL PROPERTIES}

- Jatropha is used for diseases like cancer, piles, snakebite, paralysis, dropsy etc.

- Jatropha 1-2 roasted seeds are reported to act as a purgative but larger doses may be dangerous. The seeds have been substituted for castor oil and are sometimes called 'larger castor oil'. The oil is widely used for skin diseases and to soothe pain such as that caused by rheumatism.

\section{ALTERNATIVE TO PETROLEUM DIESEL}

There are a number of varieties of Jatropha. Best among these is Jatropha curcas as it yields oil bearing seeds. Some of the others are

Jatropha curcas (nontoxic)

Jatropha curcas $x$ Jatropha integrerrima

Jatropha gossypifolia

The chemical properties of jatropha oil are given below 


\begin{tabular}{|l|l|}
\hline Item & Value \\
\hline Acid Value & 38.2 \\
\hline $\begin{array}{l}\text { Saponification } \\
\text { Value }\end{array}$ & 195.0 \\
\hline Iodine Value & 101.7 \\
\hline $\begin{array}{l}\text { Viscosity(at } \\
\text { 31 }^{\circ} \text { C), } \\
\text { Centistokes }\end{array}$ & 40.4 \\
\hline
\end{tabular}

\section{MATERIALS AND METHODS}

\section{A. Sample Preparation}

About 100gms of Jatropha seeds were taken from the garden in Vijayawada and were grounded with the help of mortar and pestle to make the fine powder.

Extraction of oils from Jatropha curcuras $L$

Materials

1. Jatropha seeds powder

2. $95 \%$ Hexane.

\section{Procedure}

About 50gms of Jatropha seed powder was taken and transferred to the Rota evaporator and $350 \mathrm{ml}$ of $95 \%$ hexane was added. The oil was extracted by rotaevoporation at boiling point.

The operation of channel separation is applied on the watermarked color image to generate its sub images, and then 2-level discrete wavelet transform is applied on the sub images to generate the approximate coefficients and detail coefficients.

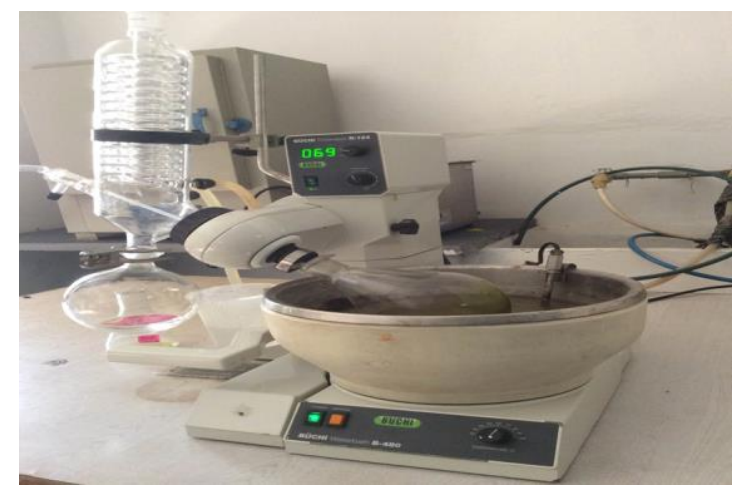

\section{B. PHYTOCHEMICAL SCREENING}

\section{Seed sample}

\section{A. TEST FOR TANNINS}

The extract taken in water and it should be warm and filtered. Nearly $50 \mathrm{ml}$ of filtrate was allowed to react with $1 \%$ of ferric chloride solution. About 3gms of extracted seed powder was dissolve in $15 \mathrm{ml}$ of distilled water and allowed to soak for at least one hour and then the sample was collected .This was filtered and then subjected to phytochemical test as test 1 sample.

Oil obtained by extraction from seeds is considered as test 2 sample for analysis

\section{MATERIALS}

1. Chloroform

2. Concentrated sulphuric acid

3. Alpha-naphthol alcoholic solution:10gms alpha naphthol dissolved in $100 \mathrm{ml}$ ethanol.

4. Ferric chloride solution 5\%: $5 \mathrm{gms}$ in $100 \mathrm{ml}$ distilled water.

5. Iodine solution: $29 \mathrm{~g}$ potassium iodide and $10 \mathrm{~g}$ iodine crystals in $100 \mathrm{ml}$ of water.

\section{B. TEST FOR STEROLS (SALKOWASKI TEST)}

Take $1 \mathrm{ml}$ of extract and dissolve it in $2 \mathrm{ml}$ of chloroform and then add $2 \mathrm{ml}$ of conc. sulphuric acid from the sides of test tube. Now test tubes was shaken for few minutes

\section{TEST FOR GLYCOSIDE}

Take $1 \mathrm{ml}$ of extract and then add $2 \mathrm{ml}$ of methanol. To this add alphanaptholalcoholic solution into the test-tube.

\section{TEST FOR SUGAR}

Small quantity of extract was dissolved in $4 \mathrm{ml}$ of distilled water and filtrate was subject to iodine test.

\section{E. TEST FOR SAPONINS}

$1 \mathrm{ml}$ of extract was diluted with distilled water to $20 \mathrm{ml}$ and shake in for 15 minutes

\section{F. Tran's esterification}

It is a process where fats/alcohol reacts chemically in presence of sodium or potassium hydroxide which acts as a catalyst

\section{TRANSESTERFICATION PROCEDURE}

2 types of methodology were implemented for transesterification

1) About $0.5 \mathrm{gms}$ of $\mathrm{NaOH}$ pellets was weighed and to make a fine powder. To $50 \mathrm{ml}$ of extracted oil $\mathrm{NaOH}$ powder was added and dissolved. After dissolving the $\mathrm{NaOH}$, the solution was undergone ultra sonication for 3-4 hours. 


\section{International Journal of Engineering Applied Sciences and Technology, 2020 \\ Vol. 5, Issue 4, ISSN No. 2455-2143, Pages 277-283 \\ Published Online August 2020 in IJEAST (http://www.ijeast.com)}

2) About $50 \mathrm{ml}$ of extracted oil was mixed with $200 \mathrm{ml}$ of methanol and mixed thoroughly and allowed to ultra sonication.

2. After a few hours the solutions were separated by the influence of sound waves.After the transesterification process is completed, the mixture is allowed to settle down for $5 \mathrm{~min}$. The product formed during transesterification was separated after vigorous shaking using a separator flask. The bottom layer consists of Glycerin and upper layer consists of biodiesel.
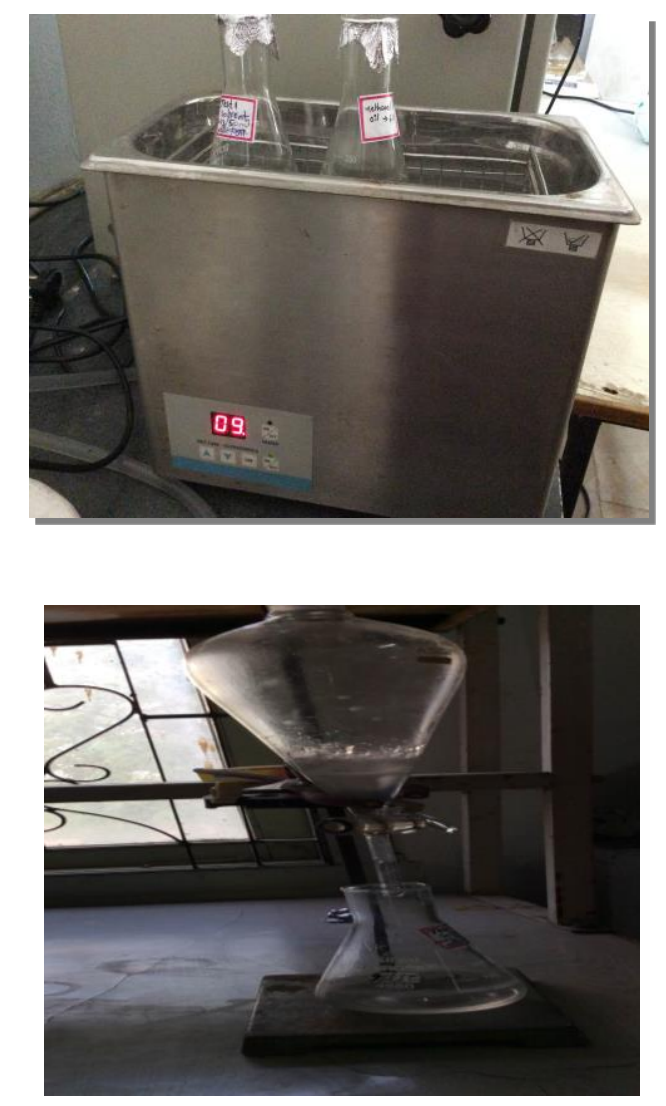

\section{ANALYSIS OF BIODIESEL AND GLYCERIN PROPERTIES}

\section{1. $\mathbf{p H}$}

After separation of biodiesel from the glycerin, the $\mathrm{pH}$ was checked with the help of universal indicator or litmus paper by taking $1 \mathrm{ml}$ of biodiesel and $1 \mathrm{ml}$ of universal indicator.

To $1 \mathrm{ml}$ of glycerin and $1 \mathrm{ml}$ of universal indicator.

\section{Freezing point:}

The two fractions were refrigerated to analyze their property at freezing condition.

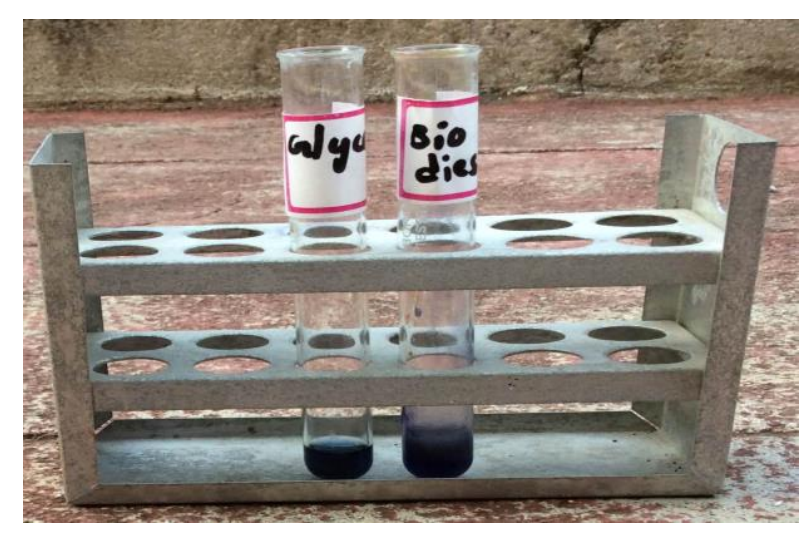

\section{Preparation Of SeEd eXtract and Coagulation ACTIVITY ANALYSIS}

The remaining seed powder after extracting the oil called as seed cake was taken and 5\% suspension was made by soaking in water for 2 hours. The sample was undergone centrifugation for $10 \mathrm{~min}$ at $5000 \mathrm{rpm}$. The insoluble materials and the supernatant was separated after centrifugation and the resulting supernatant was collected in a separate test tube. This was considered as test sample.

Two samples were considered for the analysis of coagulation activity by the seed cake extract

1) Rain water and

2) Sand water.

About $200 \mu \mathrm{l}$ of extract was added to $1800 \mu \mathrm{l}$ of rain water to this solution was made up to the volume of $2 \mathrm{ml}$. The absorbance was measured with the calorimeter for every 30 minutes time interval.

After the heat treatment:

The extract was heated for 10mins and then coagulation activity was tested. The same process was repeated again after heat treatment and finally the absorbance was measured for every 30 minute.

\section{RESULTS AND DISCUSSION}

\section{PHYTOCHEMICAL SCREENING}

The phytochemical tests for Jatropha oil extract

TABLE 1.

\begin{tabular}{|l|l|l|l|}
\hline TESTS & $\begin{array}{l}\text { Jatropha } \\
\text { oil extract } \\
\text { (Test 1) }\end{array}$ & $\begin{array}{l}\text { Jatropha } \\
\text { Seed } \\
\text { extract } \\
\text { (Test 2) }\end{array}$ & $\begin{array}{l}\text { Distilled } \\
\text { water } \\
\text { (control) }\end{array}$ \\
\hline Test of & - & + & - \\
\hline
\end{tabular}


Published Online August 2020 in IJEAST (http://www.ijeast.com)

\begin{tabular}{|l|l|l|l|}
\hline Sterols & & & \\
\hline $\begin{array}{l}\text { Test of } \\
\text { Glycoside }\end{array}$ & - & - & - \\
\hline $\begin{array}{l}\text { Test of } \\
\text { Tannin }\end{array}$ & - & - & - \\
\hline $\begin{array}{l}\text { Test of } \\
\text { Sugar of }\end{array}$ & + & - & - \\
\hline $\begin{array}{l}\text { Test of } \\
\text { Saponin }\end{array}$ & - & - & - \\
\hline
\end{tabular}
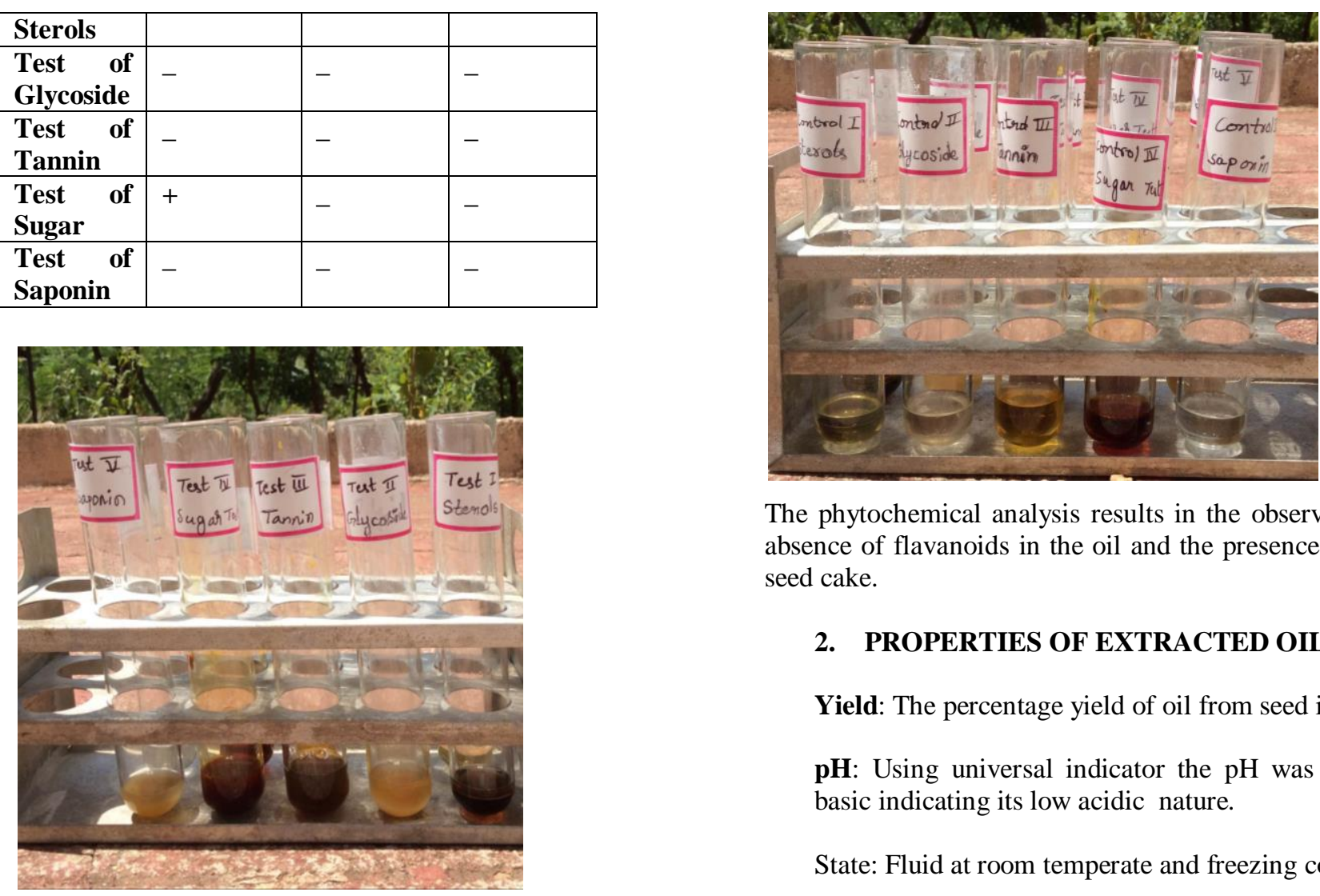

The phytochemical analysis results in the observation of, the absence of flavanoids in the oil and the presence of sterols in seed cake.

\section{PROPERTIES OF EXTRACTED OIL}

Yield: The percentage yield of oil from seed is 50\%.

pH: Using universal indicator the $\mathrm{pH}$ was found to be basic indicating its low acidic nature.

State: Fluid at room temperate and freezing condition.

\section{PROPERTIES TRANSESTERIFICATION OF OIL}

AFTER

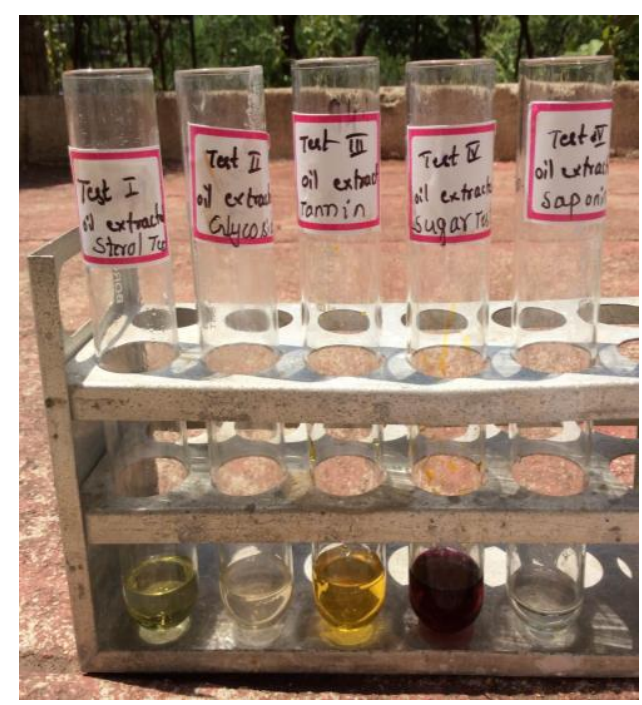

\section{A. Biodiesel: Methyl esters}

Yield: The percentage yield of oil from seed is $40 \%$

pH: Using universal indicator the $\mathrm{pH}$ was found to be basic.

State: Fluid at room temperate.

\section{B. Glycerin}

Yield: The percentage yield of oil from seed is $60 \%$.

1. $\mathbf{p H}$

Using universal indicator the $\mathrm{pH}$ was found to be basic.

\section{State}

Gel at room temperate.

\section{COAGULATION ACTIVITY OF SEED CAKE}

TABLE 2. Sample 1/ rain water 
International Journal of Engineering Applied Sciences and Technology, 2020

Vol. 5, Issue 4, ISSN No. 2455-2143, Pages 277-283

Published Online August 2020 in IJEAST (http://www.ijeast.com)

\begin{tabular}{|l|l|l|}
\hline $\begin{array}{c}\text { RAIN } \\
\text { WATER }\end{array}$ & ABSORBANCE & TIME \\
\hline BLANK & 0.00 & $3: 16$ \\
\hline 1 & 0.15 & $3: 16$ \\
\hline 2 & 0.15 & $3: 46$ \\
\hline 3 & 0.11 & $4: 16$ \\
\hline 4 & 0.11 & $4: 46$ \\
\hline
\end{tabular}

Graph 1

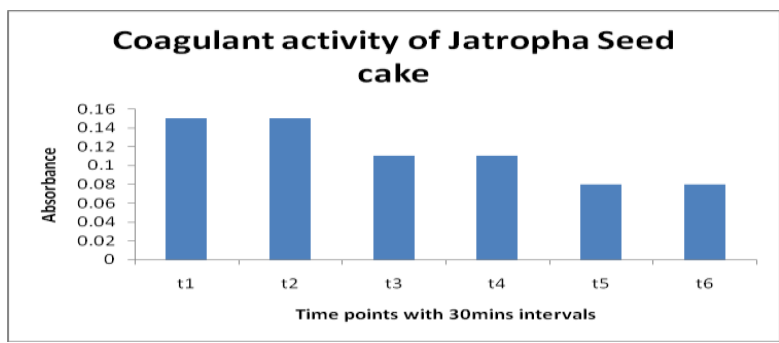

Table 3. Sample 2/ Sand water

\begin{tabular}{|l|l|l|}
\hline $\begin{array}{l}\text { SAND } \\
\text { WATER }\end{array}$ & ABSORBANCE & TIME \\
\hline BLANK & 0.00 & $5: 30$ \\
\hline 1 & 0.08 & $5: 30$ \\
\hline 2 & 0.07 & $6: 00$ \\
\hline 3 & 0.05 & $6: 30$ \\
\hline 4 & 0.00 & $7: 00$ \\
\hline
\end{tabular}

Graph 2

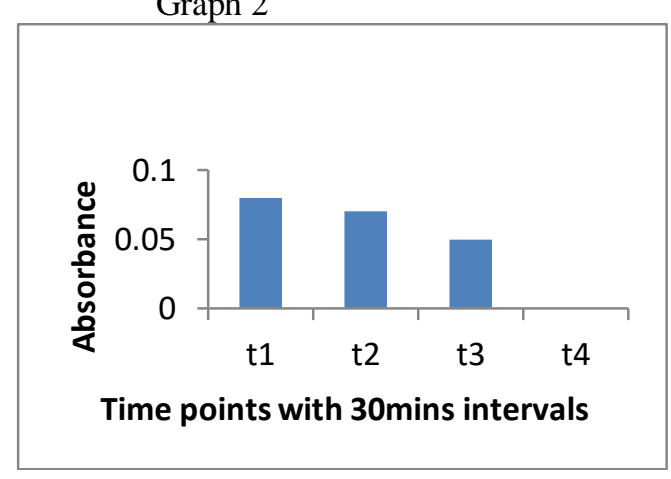

5. ANALYSIS FOR TEMPERATURE STABILITY OF COAGULANT PROPERTY

TABLE-4. Sample 3/ rain water

\begin{tabular}{|l|l|l|}
\hline $\begin{array}{l}\text { RAIN } \\
\text { WATER }\end{array}$ & ABSORBANCE & TIME \\
\hline BLANK & 0.00 & $12: 00$ \\
\hline 1 & 0.04 & $12: 00$ \\
\hline 2 & 0.02 & $12: 30$ \\
\hline 3 & 0.01 & $1: 00$ \\
\hline 4 & -0.01 & $1: 30$ \\
\hline
\end{tabular}

Graph -3

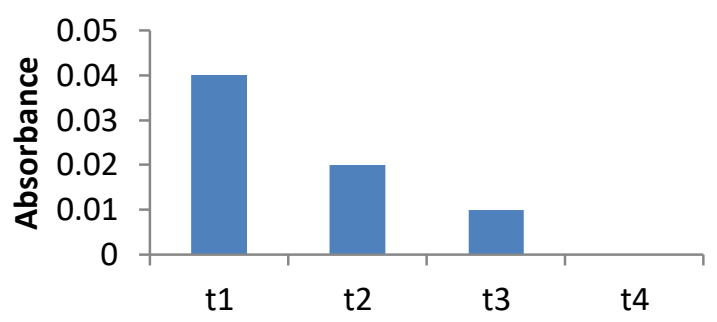

Time points with 30 mins intervals

TABLE 5. Sample 4/ Sand water

\begin{tabular}{|l|l|l|}
\hline $\begin{array}{l}\text { SAND } \\
\text { WATER }\end{array}$ & ABSORBANCE & TIME \\
\hline BLANK & 0.23 & $2: 30$ \\
\hline 1 & 0.42 & $2: 30$ \\
\hline 2 & 0.24 & $3: 00$ \\
\hline 3 & 0.06 & $3: 30$ \\
\hline 4 & -0.03 & $4: 00$ \\
\hline
\end{tabular}

Graph 4

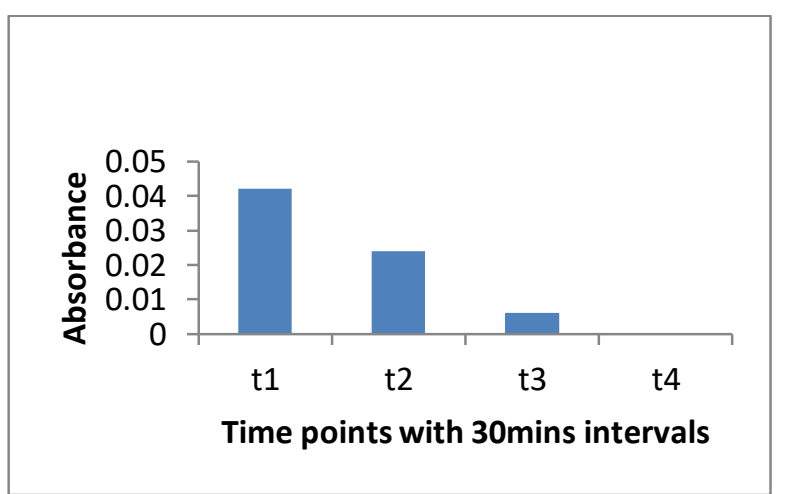


From above analysis, the Seed cake is found to have the property of coagulation which is thermo stable. The property could be due to the sterol component in the seed cake extract which is evident in the phytochemical screening.

\section{CONCLUSION}

The present study helped in the production of biodiesel from Jatropha curcuas $L$ seeds with less time reaction time using catalyst, solvent and ultra sonication and Transesterification process. The chemical properties of biodiesel produced to be further analyzed. And also the potential coagulant activity of seed cake was also proved which is to be further analyzed for the pure component for the activity

\section{ACKNOWLEDGEMENT}

Authors owe a deep debt of gratitude to Mr. Surya AnjaniKumar.S, Director of Peptides, Vijayawada for considering and accepting my request to work under his guidance and for his continuous support and encouragement through each step of my experiments and interpretations.

\section{REFERENCES}

[1] Kuan I.-C, Kao W.-C, Chen C.-L, and Yu C.-Y.(2018). "Microbial biodiesel production by direct trans esterification of rhodotorula glutinis biomass," Energies, vol. 11, no. 5, pp. 1036

[2.] Satyendra Nath Mishra.( 2014). Design of Resource Use: case of jatropha based biodisel in India. Journal of Rural Development, 33(1).PP. 1-13.

[3] Elkady M. F, Zaatout A , and Balbaa O,(2015) "Productionof biodiesel from waste vegetable oil via KM micromixer," Journal of Chemistry, Article ID 630168, PP.9

[4] Chayanant Hongfa, Peerada Samunual, Suchanuch Sachdev, and Cherry Lim .(2013). Thermomorphic Biphasic System-A Greener Alternative Route to the Synthesis of Biodiesel. Energy \& Fuels ,27 (2) , PP.879-882

[5]Ekundayo FO, Adeboye CA, Ekundayo EA . (2011).Antimicrobial activities and phytochemical screening of pignut (J. curcas Linn.) J. Med. Plants Res. pp 1261-1267.

[6]Oskoueian, E., Norhani Abdullah, Syahida Ahmad, Wan Zuhainis Saad, Abdul Rahman Omar, \& Ho, Y. W. (2011). Bioactive compounds and biological activities of Jatropha curcas L. kernel meal extract. International Journal of Molecular Science, (12): 5955-5970 Oyi, A. R. Onaolapo, J.A \& Adigun, J. O. (2002). Phytochemical and antimicrobial Screening of the latex of Jatropha curcas Linn (Euphorbiaceae). Journal of phytomedicine and Therapeutical(1\&2),pp. 63-74
[7]S. F.; Holser R. A. (2007)Evaluation of biodiesels from several oilseed sources as environmentally friendly contact herbicides. Ind. Crop Prod.,26: pp. 63-68

[8]vasudevan P. T.; Briggs. (2008) M . Biodiesel production current state of the art and challenges. J. Ind. Microbiol.Biotechnology, 35: PP .421-430

[9]Wang P. S.; Tat M. E.; Van Gerpen J. (2005) The production of fatty acid isopropyl esters and their use as a diesel engine fuel. J. Am. Oil Chem , pp. 845-849

[10]Williams, A.; McCormick, R. L.; Hayes, R. R.; Ireland, J.; Fang, H. L. (2006) . Effect of biodiesel blends on diesel particulate filter performance. SAE Tech Pap Ser, pp. 3280

[11] Willing A. (1999), Oleochemical estersenvironmentally compatible raw materials for oils and lubricants from renewable resources, FettLipid, 101: PP .192198

[12] Bradley D. Whalen, Michael R. Morgan, Alex T. McCurdy, Robert M. Willis, Michael D. Morgan, Daniel J. Dye, Bruce Bugbear, Byard D. Wood, and Lance C. Seefeldt (2013). Biodiesel from Microalgae, Yeast, and Bacteria: Engine Performance and Exhaust Emissions. Energy \& Fuels , 27 (1), PP. 220-228

[13] Prafulla D. Patil, Veera Gnaneswar Gude, Lucy Mar Camacho and Shuguang Deng.( 2010)Microwave-Assisted Catalytic Transesterification of Camelina Sativa Oil. Energy \& Fuels , 24 (2) , PP.1298-1304 